\title{
THE FAMILY WAGE ECONOMY OF A FRENCH TEXTILE CITY: ROUBAIX, 1872-1906*
}

\author{
Louise A. Tilly**
}

Jack Goody, with Joan Thirsk and E. P. Thompson, has recently edited Family and Inheritance, a volume of essays from the 1974 Past and Present Conference on the family. Goody's introduction to the volume puts family history into the context of the analysis of inheritance systems. Social historians have long studied inheritance patterns, but that inquiry and family history have gone on in nearly total isolation from each other. Goody notes that inheritance is

not only the means by which the reproduction of the social system is carried out (in so far as that system is linked to property, including the ownership of the means by which man obtains his livelihood); it is also the way in which inter-

*This paper is a revised and enlarged version of "Production and Reproduction: Economic Links of Work and Family in Early Industrialization," a paper read to a Symposium on Social Theory and Social History, Columbia University, February 19, 1977. Thanks for their comments at the meeting to Rayna Reiter, William J. Goode, Lawrence Stone, and other members of the audience. Joan Scott, Lynn Lees, M. J. Maynes, Elizabeth Pleck, Miriam Cohen, and Charles Tilly read and commented on earlier versions. At the meeting of the Social Science History Association, October, 1977, Tamara Hareven and David Levine commented on the paper. My thanks to them and members of the audience as well.

${ }^{* *}$ Louise A. Tilly, associate professor of history at the University of Michigan, Ann Arbor, received her Ph.D. from the University of Toronto. She and Joan Scott co-authored Women, Work and Family (Holt, Rinehart and Winston, 1978). She is presently writing a comparative study of family and industrial. ism in France.

\begin{abstract}
personal relationships are structured.... A different quality of relationships, varying family structures, and alternative social arrangements (e.g., greater or less migration, age of marriage, rates of illegitimacy) will be linked to differing modes of transmission.... The inheritance system of any society . . . is the way by which property is transmitted between the living and the dead. ... It is part of the wider process whereby property relations are reproduced over time (and sometimes changed in so doing). . . . (Goody, 1976:2-3)
\end{abstract}

The essays which follow Goody's introduction convincingly demonstrate that the historical study of inheritance, far from being dry and legalistic, is full of vitality and productive of original insights into family relationships in the past.

One question occurs immediately to the nineteenth-century historian: when there is no property to transmit, is there some equivalent to the neat integrative concept of inheritance? What aspect, if any, of the economic and social system of industrializing Europe plays the same key role of shaper of interpersonal relationships and reproducer of the social system? The answer is that wages, and the access of family members to wage earning, were a powerful organizing principle of family life in the early industrial cities of Europe.

One of the chief phenomena accompanying the substitution of an industrial mode of production for the domestic or household mode which predominated in peasant agriculture and urban artisanal production was the monetization of peo- 
ple's relationships to production and to each other. There was a vast increase in the number of persons who owned or controlled no property, who possessed no skill or tools to pass on to their children. The number of persons who earned wages increased, as did the proportionate importance of households in which they lived. The new proletarians worked for wages and had little or no control over the conditions of their labor. There had been wage earning proletarians before 1800 in Europe: some lived in cities as service workers, hired laborers, and the like. Others lived in the countryside as agricultural laborers and rural outworkers. Both proletarians and propertied persons lived in domestic groups or households in which reproduction and consumption were carried on. Their own household was the locus of production for propertied domestic groups. Proletarians worked sometimes on the account of others in their own household, sometimes in another household, sometimes in the relatively few but increasing non-household productive units.

Property owning families lived in an economic and social situation dominated by the fact of property, their familial and other relationships influenced by the need to preserve a patrimony, the possibility (or danger) of dividing it, or anticipation of future gain. Proletarian families' lives were shaped by the wage family members could earn, by the number of household members to earn them, and by the spatial arrangements of home and workplace. As industrialization led to increasing proportions of wage earners, the family relationships formerly characteristic of relatively few became the relationships of the majority. The history of the family in nineteenthcentury Europe, in contrast to that of earlier periods, must therefore deal with proletarian as well as propertied households.

The demographic record-keeping of nation states in the forms of census and vital record registration provides a source which is as valuable as the early modern contracts, custumals, and wills for information about certain family relationships. In the original census schedules, or in the lists of individuals which were compiled by census takers, can be found information for individuals identified as within households: age and sex, kin relationships, occupation, sometimes place of birth and nationality, and occasionally, place of employment. Persons can be examined simultaneously as individuals of given age and sex, as workers, as members of coresiding households and of nuclear families. Simultaneously, the same attributes can be examined for others in the unit. Many aspects of family life fall outside these realms, and information about them must be sought elsewhere, but the study of censuses can reveal an economic system of production and reproduction. It links work and family on the household level and lays out the material base for social relationships in industrial society. These characteristics of households can then be compared over time and from one city to another, across regions, national boundaries, and so on.

Household and family are the units of analysis; the individual is examined within the household context because it is there that reproduction and consumption take place. Although, with industrialization, production goes on elsewhere, there is nonetheless a residual involvement of family with production: it is within the family that decisions about wage earning are made in order to accumulate cash for consumption needs. And any surplus cash, once such needs are satisfied, is allocated to other uses, personal or otherwise. This view moves from a "top-down" interpretation of production as the process which dictates the needs for reproduction of the labor force. It focuses on family units caught up in industrialization and proletarianization-families which were mi- 
grating to cities, whose members were earning wages, and whose strategies about child bearing, child nurture, child socialization and control were shaped by these processes. The family, then, was the mediating institution between individuals and processes of large scale structural change in which they found themselves.

This paper examines a French textile manufacturing city, Roubaix. It seeks to determine how opportunities for wage labor shaped family structure and affected the activities of family members who lived in a situation of physical separation of home and work place, over the period from 1872 to $1906 .{ }^{1}$ In order to do this, it focuses on women and children in Roubaix families. The evidence is grouped to answer three large questions: How were family fertility strategies affected by opportunities for women's and children's wage labor? How were family decisions on who should do wage labor affected by opportunities for women's and children's wage labor and household service needs? What was the basis for coresidence of young persons in the industrial city? These questions all focus on the relationship of a child with his or her family of origin, and particularly with the mother of this family. The conclusion looks at the working-class way of life, which predicated continued coresidence of children until marriage. This behavior was common not only among the proletariat of the textile city of Roubaix at the turn of

'The researeh for this paper was supported by a Rockefeller Foundation Population Policy Grant, 1974-1976, and by a Rackham Faculty Grant, 19761977. The projects were comparative studies of "Women in an Urban Industrializing Society" and "Education and the Working Class in Three French Cities." The basic data for Roubaix were found in the nominal lists of the French census for the years 1861, 1872 , and 1906 which are located in the Municipal Archives of Roubaix $(1861,1872)$ and in the Archives départementales du Nord in Lille (1906). All population data in this paper are based on a ten percent sample of households from these lists. the century, but among most urban working classes from that period to the present. The economic basis for this "customary" behavior will be discussed. There is much more to any group's family life than economic calculation. The kind of evidence here assembled, however, is most meaningfully employed in examining simple economic links between work and family in a situation in which labor is the chief resource of families.

Roubaix is a wool textile producing city in the department of the Nord, located at the Belgian border. In Roubaix, factories first developed on a large scale in the 1860 s, when the city boomed on wool production, in place of earlier cotton and mixed textile industries. In 1872, the textile industry employed over 50 percent of the labor force; almost half the textile workers were female. These workers were mostly unmarried girls: 81 percent of single females (over 15) but only about 17 percent of married women worked. Fiftyfour percent of the married women who worked were textile workers. The rate of labor force participation of young people aged 10 to 14 was also high: 40 percent for girls, and 37 percent for boys. It is clear, therefore, that there were wage earning opportunities for women and girls, but also for the young of both sexes. The labor force, especially female, was very young: 82 percent of female textile workers and 49 percent of male were under 30 .

Roubaix is in no way "typical" of French cities. Nor is its occupational structure and family response "typical" of nineteenth-century industrial cities, of which textile cities are but one case. The experience of Roubaix, however, has a lot in common with other textile cities whose industrial activity produced a labor market with demand for young women and children workers in its early phases. Later, when the European textile industry began to suffer from overseas competition, most textile cities shared with Roubaix the 
phenomenon of growth of labor force participation by married women.

The demand for labor attracted thousands of Belgian and French migrants to the city. Fifty-six percent of Roubaix's inhabitants were of foreign nationality in 1872. Whether French or Belgian, however, many of the workers who migrated to Roubaix in this period-and the city was growing to a large degree by migrationhad already worked in the then-declining putting out or domestic industry of French and Belgian Flanders. Migrants were to a large degree already accustomed to earning wages; moving to the city did not change that aspect of their lives. What did change was the location of work. In the city, textile work was to be found in large scale units rather than in the household units typical of the putting out industry.

Although families were entering a new environment, their basic consumption needs remained unchanged. These were determined by household composition, the number of family members, and their age and sex mix. Proletarian families had very little to say about the productive system in which they worked. They had migrated in search of new opportunities for wage earning in Roubaix. Adjustments in household size and composition and in which members did wage work were ways that they could adopt to deal with changed circumstances. They constantly had to seek ways to maintain a balance between producers and consumers, and an adequate family income. As Thomas C. Smith points out in his study of a Japanese village, "What is required is a lively appreciation of the relation of the size and composition of the family to its welfare; and this idea does not seem intrinsically more difficult for premodern people to grasp than the notion that improvements in agriculture required long-term effort (Smith, 1977:147. See also Thorner et al.: 1966)."
Families adjusted when they came to the city; they continued to adjust as conditions changed. How families coped can be traced through the historical record of family interaction with the labor market in three areas, which correspond to the three questions laid out above. These are: family fertility strategy, and the dual roles of women as producers and as reproducers; the choice of family members who would do paid market work over the family cycle; and the pattern of coresidence of adolescent and adult children with their families, as evidence of how long children stayed at home, working in the family wage unit.

\section{Fertility Strategy}

From the point of view of families, reproduction is a more flexible system than production. Families can adjust and modify reproductive strategy, whereas production is a system outside the range of an individual family's control. This insight is derived from Claude Meillassoux' recent book, Femmes, greniers et capitaux (Paris, 1975), which examines families in agricultural communities constrained by a relatively unproductive agriculture. These families nevertheless interact actively with their particular relations of production. Complementary relations of reproduction are necessary to perpetuate the domestic productive unit. Productive relations develop through control of the distribution of agricultural products, which are under the control of elders within each household, and within the society, of households headed by senior heads. The relations of reproduction on the household and societal level develop from the need for a balance between productive and non-productive individuals. Elders within households are the powerful decision makers on questions of reproduction. There is also a reproductive system at the level of society because of natural limits on small groups 
through death, sterility, unbalanced sex ratio, and so on. But, Meillassoux insists, reproduction is more flexible and more responsive to needs on the household level than is production. Changes in production are limited by low levels of technical knowledge and productivity; and all that even the most powerful individuals and households can do is hoard and try to control distribution. There are more possibilities of variant responses in the realm of reproduction to make it conform to the material imperatives of production. In fact, in the process, some reproductive decisions can modify productive possibilities.

Wage earning families within capitalist productive systems in nineteenth-century industrialization had behavioral constraints and opportunities similar to those of the families described by Meillassoux. Wage earning families were totally separated from the property owning classes, and they had no control over production decisions. Their rules of behavior were similar to those of families whose production was subject to vagaries of weather. For both groups, labor allocation and reproductive strategy were important behavioral responses because labor was the chief resource which they could dispose of. There were many opportunities for earning wages open to the proletarian families; but the opportunities were for workers whose characteristics were defined by others, outside the family, by the technical characteristics of occupations, and by preferences of employers for workers of given age and sex. This situation was typical of early industrial jobs in textiles. In textile towns, capitalist industrial production offered jobs for workers, but workers and their families had little influence on the wages they were paid, or on the age and sex mix of desirable workers. The hierarchy of wealth and power which they had to deal with was both wealthier and more institu- tionalized than the hierarchy of elders in the agricultural economy which, according to Meillassoux, dominated the distribution of the product. Yet two aspects are similar: the relative powerlessness of families in both situations, and the way factors outside of family control influenced labor demand for family members.

Family fertility strategy in early textile towns had to deal with deep and painful contradictions (Litchfield, 1978). On the

FIGURE 1. AGE-SPECIFIC CHILD-WOMAN RATIOS: CHILDREN UNDER 5 PER THOUSAND WOMEN, AGED 20-49, ROUBAIX, 1861 AND 1872.

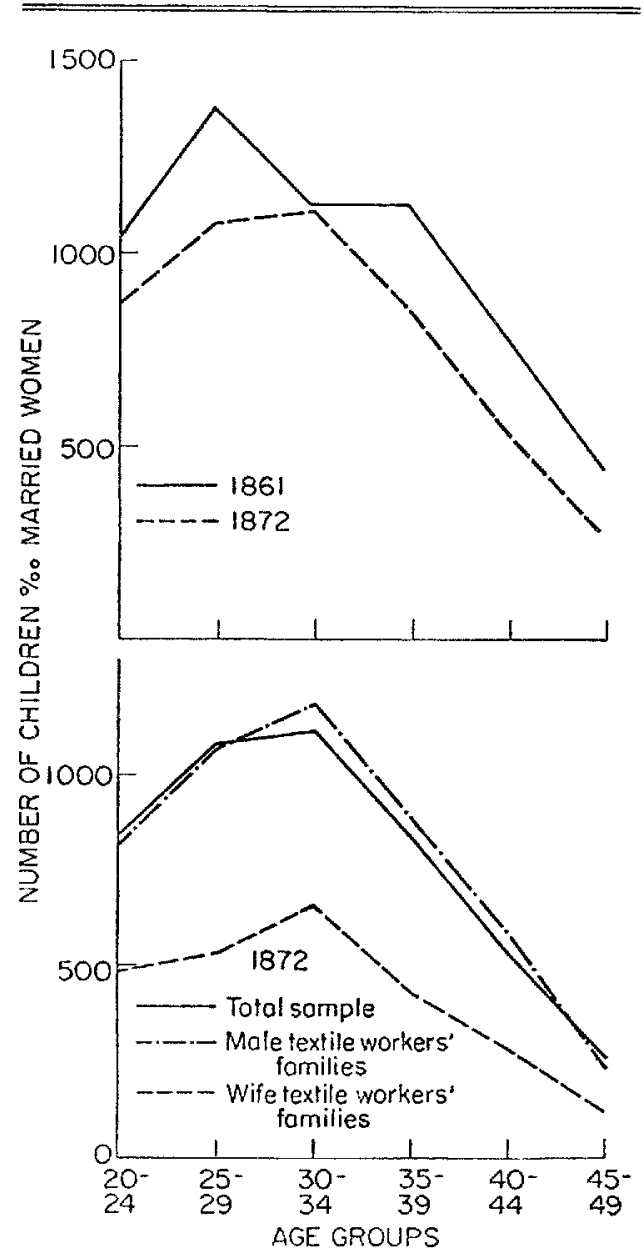


one hand, there were many jobs for women. On the other, there were many jobs for children. Under these conditions, did families choose to send wives out to work or to have more children? In fact, fertility was high in early industrialized textile cities, even when the young age structure of the population is taken into account. Figure 1 shows age specific childwoman ratios for Roubaix in 1861 and $1872 .{ }^{2}$ This measurement counts the number of children under five (living in households with both their parents) per mothers, by age group, aged 20-49. The advantage of this age-specific child-woman ratio calculated from census figures is that fertility levels can be linked with individual and household characteristics, such as age of mother, occupation of mother, and occupation of father. The 1872 curve of children under five per thousand wives shows a higher level at ages 30-34 than in earlier age groups. This is consistent with relatively late age of marriage, for couples would have more children under five in the first years of marriage than at later periods.

There was a tension between generational interests in families. Parents wished to keep their children in the household as wage earners, which tended to push marriage age up. Late marriage, then, put the catch-up effect of rapid child bearing during the early years of marriage within an older age group of women. Once a couple married and left the household of their parents there was a tension between wives' roles as producers and reproducers. There were good wage earning opportunities for wives under 30 , which may have delayed childbearing somewhat. Once child bearing started, however, it was opportunities for child workers which shaped household fertility strategy and dictated large families. But since it would be many years before children could bring in income, the young wife whose family needed her wages often continued to work when she had young children.

Panel 2 of Figure 1 shows child-woman

\footnotetext{
${ }^{2}$ Discussion of method for calculating of age-specific child-woman ratios from census and their usefulness as a fertility measure is found in Hareven and Vinovskis, 1974 and 1975. Numerical values of the child-woman ratios are shown in the following table.
}

TABLE 1. CHILD-WOMAN RATIOS (CHILDREN UNDER FIVE TO 1,000 WIVES BETWEEN 20-49 LIVING WITH HUSBANDS).

\begin{tabular}{|c|c|c|c|c|c|c|c|}
\hline Roubaix & & 1861 & $\begin{array}{c}\mathrm{N} \\
\text { (Wives) } \\
\end{array}$ & 1872 & $\mathrm{~N}$ & 1906 & $\mathrm{~N}$ \\
\hline $\begin{array}{l}\text { Total Sample } \\
\text { Raw } \\
\text { Standardized* }\end{array}$ & , & $\begin{array}{l}1,013.3 \\
1,020.0\end{array}$ & 677 & $\begin{array}{l}827.0 \\
814.7\end{array}$ & 1,174 & $\begin{array}{l}432.9 \\
433.0\end{array}$ & 1,681 \\
\hline $\begin{array}{c}\text { Male Textile } \\
\text { Heads }\end{array}$ & $\begin{array}{l}r \\
s\end{array}$ & $\begin{array}{l}1,069.7 \\
1,084.6\end{array}$ & 330 & $\begin{array}{l}862.5 \\
837.8\end{array}$ & 510 & $\begin{array}{l}422.6 \\
424.8\end{array}$ & 620 \\
\hline $\begin{array}{l}\text { Non-Head Textile } \\
\text { Worker in } \\
\text { Family }\end{array}$ & $\begin{array}{l}r \\
s\end{array}$ & $\begin{array}{l}679.5 \\
484.2\end{array}$ & 78 & $\begin{array}{l}643.1 \\
695.1\end{array}$ & 353 & $\begin{array}{l}319.4 \\
325.8\end{array}$ & 479 \\
\hline $\begin{array}{c}\text { Wife Textile } \\
\text { Worker }\end{array}$ & $\begin{array}{l}\mathbf{r} \\
\mathrm{s}\end{array}$ & $\begin{array}{l}0 \\
0\end{array}$ & 0 & $\begin{array}{l}493.1 \\
437.3\end{array}$ & 146 & $\begin{array}{l}209.6 \\
157.5\end{array}$ & 291 \\
\hline
\end{tabular}

* Standardized to age distribution of married women in Hareven and Vinvoskis samples. Journal of Social History, 1975. 
ratios for selected occupational groups in 1872. The graphs for wives of male textile workers closely paralleled that of the total sample, except that fertility was somewhat higher in the older age groups. Overall, fertility had declined in comparison with 1861 , but Roubaix families in general, and textile families in particular, were producing very large completed families. The imperative at all times to have more than one family wage earner was a powerful factor in this kind of family strategy. Given high rates of infant mortality in Roubaix (239/ 1000 births in 1873-1875), textile families had to have many children if several were to survive to working age and contribute to the family wage fund. ${ }^{3}$

Wives who were themselves textile workers had much lower fertility than either the total sample or the wives of male textile workers as a whole. The sharp peak in age group 30-34 in the textile wife subsample echoes total sample behavior and probably also shows the catch-up effect of late marriage. The number of textile wives over 30 is quite small, and they are anomalous not only because they were working wives, but also because they were old as textile workers. Their low fertility makes sense, but what it means is not clear. The direction of possible causal links between working wives and lower fertility cannot be deduced from these data. Wives could be working because they had few children, or they could be having few surviving children because they were working. Furthermore, it is quite possible that the recorded low child-woman ratios for these wives were less accurate than those for other wives be-

${ }^{3}$ Estimated net completed fertility, based on the 1872 child-woman ratios, i.e., completed fertility assuming that the age specific rates of 1872 continued over the reproductive life of women then aged 20 , was 4.8 children. The child-woman ratio only counts surviving children under 5 (and surviving mothers), not children ever born or all mothers, so that true fertility was certainly much higher. cause of differentials in infant mortality between children of working and non-working mothers. The lower child-woman ratios of textile worker wives in Roubaix could reflect higher infant mortality in this group as well as lower fertility. The high fertility of Roubaix families, which seem to have expected women to be reproducers and producers, was modified over time as families adapted to the combination of need and opportunity which faced them in the city.

FIGURE 2. AGE-SPECIFIC CHILD-WOMAN RATIOS: ROUBAIX, 1906.

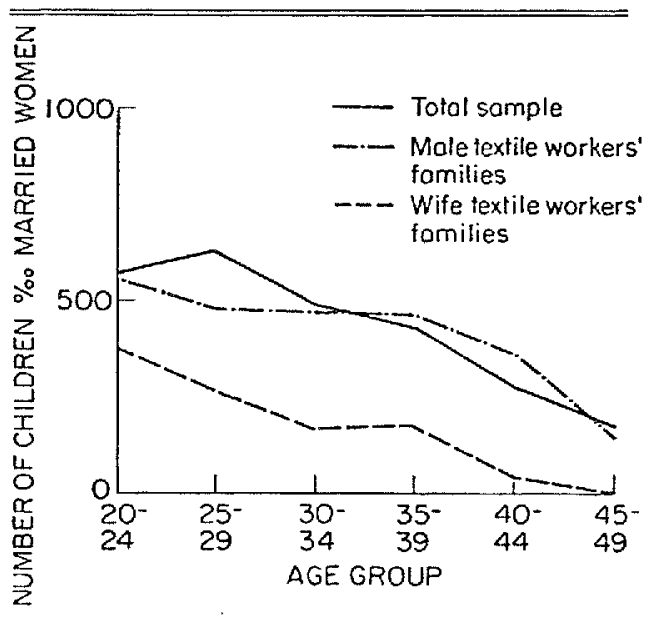

Figure 2 shows child-woman ratios for sample families in which parents were both resident in 1906. Curves for the total sample and for textile worker-headed families show a sharp decline over 1872 . The graph of female textile workers had not declined as sharply, but its modification from convex to concave shape strongly suggests that some means of birth control was used by these women (Knodel, 1977: 220).

The implications for women of this fertility decline are enormous. Women were no longer burdened with numerous births, heavy responsibility for infant and child care, and infant death. Their labor force participation no longer threatened their 
infants' lives. The average number of persons in Roubaix per family had dropped from 4 to 3.5 from 1872 to 1906 .

\section{Family Wage Labor Decisions}

Recent interpretations of women's economic activity have made a strong case for a broader view of the range of activities included in the scope of "economics." (Goody, 1973; Lloyd, 1975; Boulding, 1976; Hartman, 1976; Mason, Vinovskis, and Hareven, 1979) Wives' contribution to a household economy goes far beyond any wage they can earn. Cooking, care of clothing and home for wage earners, childbearing, and child care must be taken account of in any analysis of women's economic role. Goody (1973:186) notes sexual pleasure as another contribution. Among proletarian families, the fact that the little saving and the few leisure moments were a consequence of wives' economical management and self-denial is also important. In the city of Roubaix, over the entire period examined, married women both earned wages and bore children. They adopted a life cycle rhythm of wage work and home work which was consonant with the children in their household beginning to do wage labor as they grew up, and the consequent increase of service activity by their mothers that this made possible.

The pattern of availability of women's and children's wage work in Roubaix in 1872 and the family cycle of need led to a cyclical pattern of employment for wives and children shown in Figure 3. The major wage earner in most families was usually the adult male head; his wages, however, were poor and his work-life cycle short. Family fortunes were closely tied to family composition over the years of family formation, growth, fission, and the eventual death of the original couple. Reybaud, a contemporary observer of textile workers' families, noted that when a couple first married, they prospered, for both could work for wages (Reybaud, 1863:115).
FIGURE 3. FAMILY CYCLE PATTERNS OF WIVES' AND CHILDREN'S WORK IN ROUBAIX, 1872.

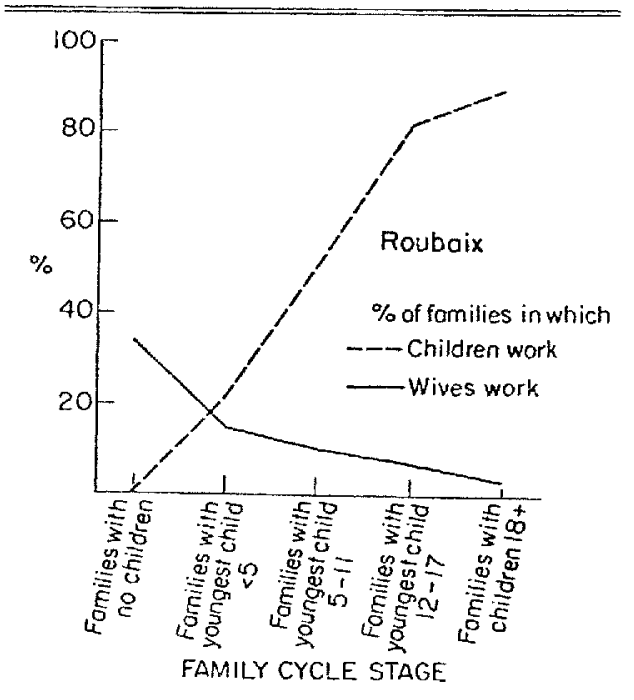

When children came, it became more difficult for the wife to do wage labor. Yet need was great at just this time, for there was a high ratio of consumers to producers. In Roubaix the consequence of family need and the pattern of wage opportunity for young women was that in 1872 the proportion of wives working continued to be relatively high even for mothers of children under five.

The factor that led to mothers' retirement from work, then, was often not the pressure of infants, but the aging of mothers and their declining ability to earn wages, and the availability of older children as workers to take the place of their mothers. As more children went to work, the mothers' labor force participation declined. Need constrained families to provide multiple wage earners; wives and children substituted for each other over the family cycle as wage earners. Some wives, then, retired from wage earning not when child care demands were highest, but when their wage earning ability declined and when substitute wage earners were available. 
Even among proletarian families, most wives were not wage earners in either period. A working wife was a sign of a very poor family, one with unusual need because of the absence of a male wage earner, his poor wages, his sickness, and so on. Wives worked when they had to and retired when they could. Their household resporsibilities did not decrease as their children became workers, for those children tended to live at home, as is shown below. The wage work of children under 15 had declined considerably by 1906 . Technological change, factory legislation, and compulsory education all contributed to this change. So did improved real wages for men. Proportionately, more females over 15 worked in the Roubaix labor force in 1906 and many more married women. In 1906, 31 percent of married women worked, as compared to 18 percent in 1872 (cf. Collet, 1898:242).

This increased proportion of married women working suggests that family decisions about which family members did

FIGURE 4. FAMILY CYCLE PATTERNS OF WIVES' AND CHILDREN'S EMPLOYMENT: ROUBAIX, 1906.

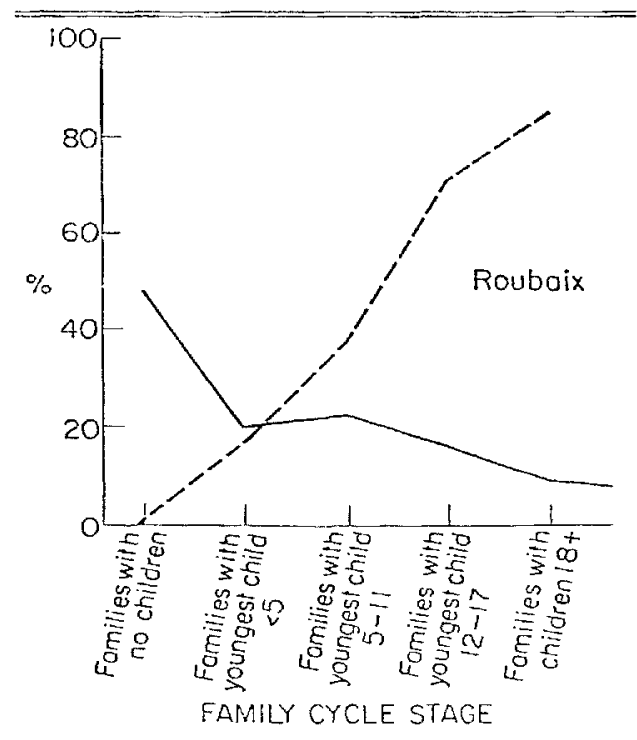

wage labor were responding to changed opportunities for children as much as to employer preference or bourgeois opinion about a "woman's place."

In 1906 (Figure 4), there were proportionately fewer families in which children worked than in 1872 , but more families in which wives worked. Wives were filling jobs formerly done by children and young persons. (The immigration of families with young working members was no longer the dominant pattern in 1906; the population of Roubaix had actually declined since the previous census in 1901.) The curve of families in which wives worked in Figure 4 dips slightly at the cycle point of families with the youngest child under five. Wives were more likely to spend time caring for young children in 1906 , even though the proportion of children working in their families climbed more slowly than in 1872 . This was made possible by the fact that adult male workers earned better wages in the more diversified urban economy of 1906. Families had more choice about whether young persons would attend school or go to work. In 1906, the proportion of children aged 10 to 14 who had occupations had dropped to 15 percent for girls, 10 percent for boys. In 1906, the proportion of children under 15 who were in school had more than doubled over that of 1872 (Roubaix, 1873 and 1907).

In Roubaix, there was increased labor force participation by married women, and a dramatic decline of wage labor by children under 15 . Nevertheless the pattern of wives and children alternating in wage labor remained. The children in 1906 were older-children in a biological and juridical sense, not in terms of age.

\section{Patterns of Family Coresidence}

An important indication of children's autonomy has been identified in patterns of residence of young persons and in the timing of their departure from their family 
of origin (Anderson, 1971:83-86; Katz, 1975:297-303; and Goody: 1972). The pattern of job opportunity for family members in wage earning families affects decisions about coresidence, and hence the size and composition of household among industrial proletarian families. Anderson (1972: 233-234) notes an apparent increased coresidence of children in Preston, an English textile city, as compared to rural areas in 1851. His evidence shows continued residence of children in their parents' households, even while the children held jobs. In Roubaix, a similar pattern obtained.

In Roubaix, as in Preston, there was an apparently successful family effort to keep children in the household and working for the family wage fund. The same proportion of the Roubaix population in 1872 as that of Preston in 1851 (49 percent) was identified in the census as children (of any age) living in households with their parents. This compares to lower proportions for England as a whole, for rural Lancashire and much lower proportions for the city of York in 1851. Compared to textile towns, all these populations had higher proportions of servants, who were, after all, primarily young persons living in households other than their parents'. The percentage of households with children (as broadly defined above), was also high in Roubaix. Figure 5 shows the number of children in Roubaix living in nuclear families by the age of mothers. The Roubaix graph shows that although the number of children in the home was highest for mothers aged 40-44, a very high average was maintained between 35 and 54. Table 2 compares Roubaix residence patterns of young persons for 1872 and 1906. The tabulations for Roubaix include young persons who were married and in their own households and, consequently, show lower proportions of young persons living with their parents than Anderson does for Preston in age group $20-24$, a category from his calculations. Nevertheless, well over half of young men and 45 percent of all young women aged 20-24 lived with their parents in 1872 Roubaix. The proportion of young persons aged 10-19 living with their parents was considerably higher in Roubaix than in Preston. Apparently intact families (or at least one parent plus children) migrated in search of jobs in the French textile city. As Anderson believes, parents and children may well have lived together longer than elsewhere under these circumstances.

Why was this? How did families keep their children at home? The wages of children under 15 were very low, for there was an age hierarchy in wages. An adult factory weaver could make 18 francs a week around 1872 in Roubaix, a good spinner, 25 to 30 francs weekly. Piecers (rattacheurs) and other auxiliary workers made 12 francs weekly. These latter were children's

FIGURE 5. RESIDENT CHILDREN PER FAMILY BY MOTHERS' AGE GROUPS: ROUBAIX, 1906.

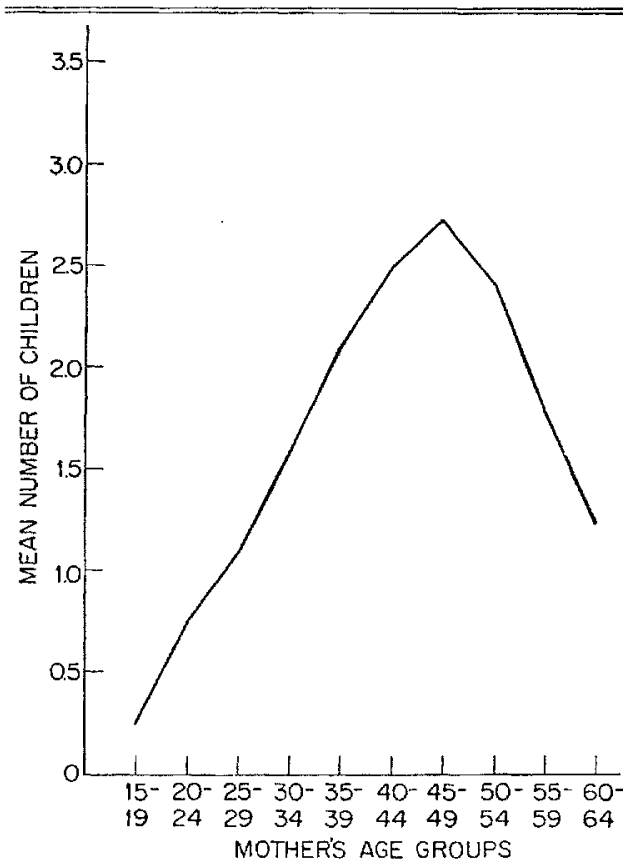




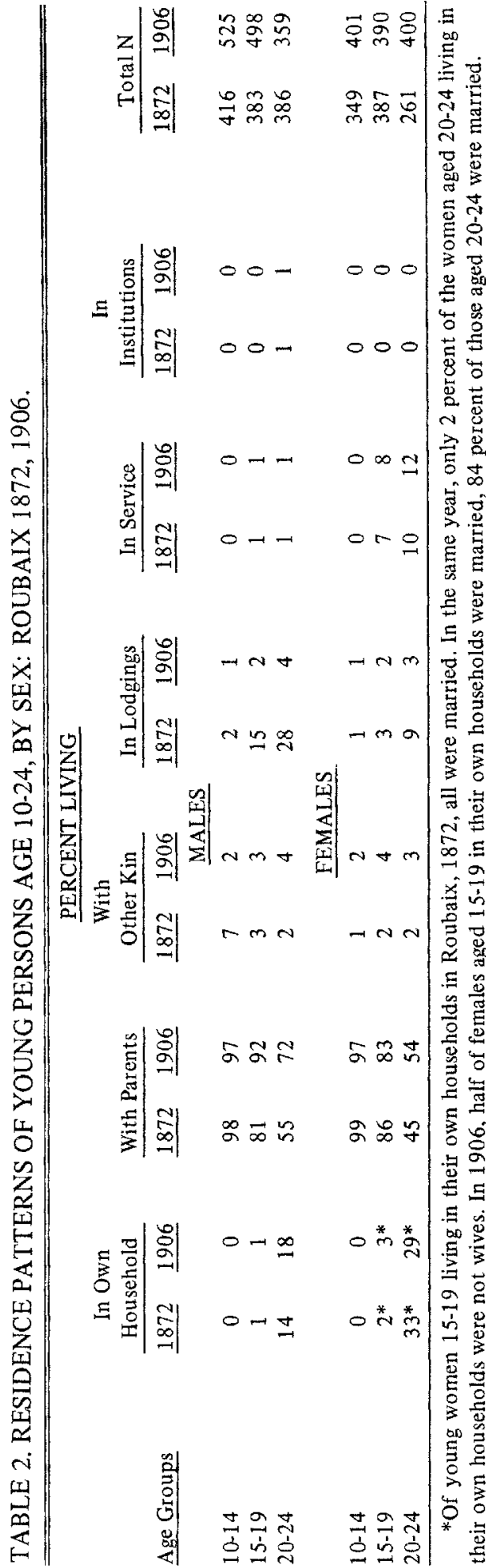

jobs--or women's. A kilo of bread cost 45 centimes, and a kilo a day was an average ration for a worker. This means that one quarter of a child's salary went for his or her bread alone (Roubaix, 1873).

Families also had resources to offer older children. For one thing, in the crowded, rapidly growing city, housing was in short supply. Unlike service or agricultural labor jobs, factory jobs provided no housing. In working class households, non-working wives, and probably working wives as well, provided cleaning, cooking, and other services for their employed husbands and children. Wider kin networks sponsored migration, and neighborhood networks of women helped with job finding. Thus, although families could have little influence on the capitalist employment structure, they did have certain resources, however small, to offer their children, which could only be enjoyed if the latter were coresident.

The continuing importance of such resources is shown by the similar patterns of coresidence of children with their parents in the 1906 figures (Table 2 and Figure 6). The shape of the curve of children in the home by the mother's age had not changed significantly in Roubaix from 1872, except that it was those mothers aged 45-49 who had most resident children in their households. The whole curve had shifted downward, of course, reflecting lower fertility. In the same period, sex ratios in the city had dropped sharply. The male to female ratio of the entire sample population in 1872 was 106; in 1906 it was 96. The sex ratio of the population over 15 was 109 in 1872,92 in 1906. Not surprisingly, female nuptiality had likewise declined. Thirtythree percent of females aged 20 to 24 were or had been married in 1872,25 percent in 1906. Among women aged 40-44, 85 percent were or had been married in 1872,77 percent in 1906.

By 1906, housing was less scarce in Roubaix, for net in-migration had been re- 
FIGURE 6. RESIDENT CHILDREN PER FAMILY BY MOTHERS' AGE GROUPS: ROUBAIX, 1872.

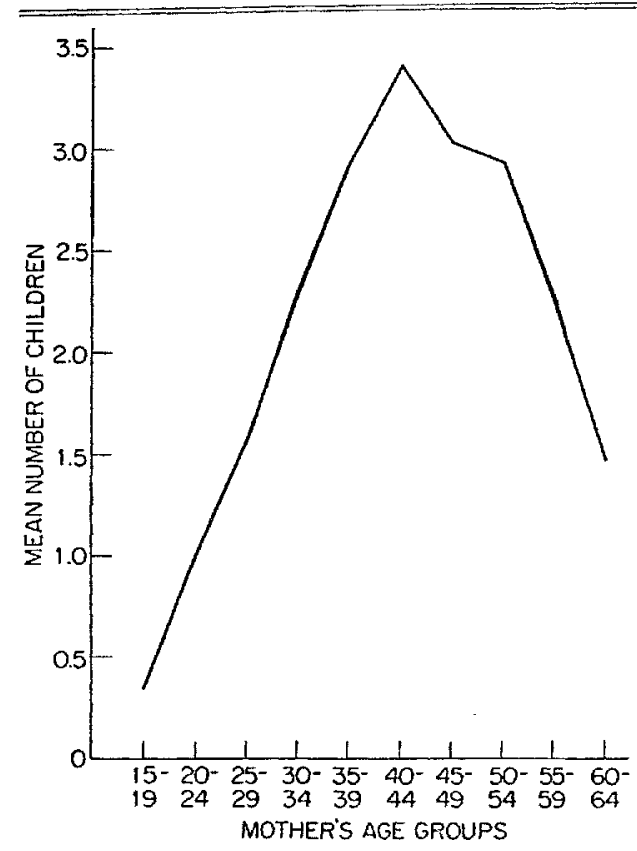

placed by out-migration. The average size of household had dropped from 4.7 in 1872 to 4.0 in 1906 . Although kin services in facilitating migration and job finding were probably not as important as in 1872 , shared wages were still very useful to families. Working children probably paid room and board to their parents, but the convenience of lodging and services rendered by the wife and mother were a real benefit to family wage earners. Lodging as a means of redistributing young people into other households with space for extra members had virtually disappeared as children stayed in their parents' households. Wives who might earlier have made a small income by taking in lodgers (Modell and Hareven, 1973) now either performed these services for their own children, or did this and held a job too. The service aspect of the family and the mother's contribution to this service look rela. tively more important in 1906 as compared to 1872 . In a family with combined wages which kept it above the subsistence level, the mother was contributing to the children's and the father's expenditure for leisure or savings by providing service at little cost.

\section{Conclusion}

The changes over time between 1872 and 1906 in patterns of family labor allocation and fertility were consequences of changing labor market conditions. The decline of child labor and the rise of married women's labor force participation were important changes in family behavior patterns. The decline of marital fertility meant that wives were less torn between wage work and child bearing or the care of small children. On the other hand, wives' increased labor force participation in this textile city did not affect the tendency of children to remain in their parents' household. Fewer children present at the older ages, as well as at the infant and early childhood ages, presumably meant less home work for an older wife. Nevertheless, her service to older children appears to have been an important factor contributing to their residence in her home. Over her lifetime, a Roubaix wife continued to divide her activities between heavy responsibilities at home and at work.

The importance of the mother for her children in working class households was noted frequently in both England and France around 1900 in the reports of contemporaries (Jones, 1974:473-76, 486-87). In England as a whole, as opposed to textile cities, the working wife was an exception. In France, higher levels of labor force participation by married women obtained, but relatively few of them worked in large scale industry like that of Roubaix. The importance of the wife's activity as provider of service and the possibility of leisure and saving for her children is underlined by evidence of such activity even in the textile city, in which wives did wage 
labor. Roubaix wives' service activity went along with a labor market which continued to provide work for young people and mature women.

As a result, most Roubaix children did not go through a stage of independence outside their own family setting in either 1872 or 1906 . Both males and females were more likely to be living with their parents in 1906 than in 1872. Marriage for young women within the city was less likely in 1906, because of the unbalanced sex ratio. However, a young man's likelihood of living in his own household increased over 1872 .

The patterns of family life among wageearning families were shaped by the powerful market conditions which they faced. Yet such families seem to have interacted purposefully with the labor market and made the most of what resources and choices they had. One cost of their decisions was the limitation of autonomy and choice for wives and children as individuals. While his work situation shaped a male wage earner's choices and autonony, the work-family link shaped those of his wife and children. In 1906, we see mother's activity contributing to leisure or to a future-oriented accumulation of savings by children.

In Roubaix, as in other nineteenth-century industrial cities, the wage economy shaped family structure and family behavior. Property holders feared and condemned the imprudence of proletarians. because property holders knew what a powerful constraint inheritance placed on their own impulses and aspirations. They did not see that wage earners experienced a different yet powerful set of constraints: the necessity and opportunity to market the household's labor power. In Roubaix and elsewhere, family reproductive strategies, family allocation of members as wage workers, and patterns of family coresidence were all part of family response to the productive system in which these families were located.

\section{BIBLIOGRAPHY}

Anderson, Michael

1971 Family Structure in Nineteenth Century Lancashire. Cambridge: Cambridge University Press.

1972 "Household Structure and the Industrial Revolution: Mid-Nineteenth Century Preston in Comparative Perspective." In Peter Laslett and Richard Wall, eds., Household and Family in Past Time, 215-235. Cambridge: Cambridge University Press.

Boulding, Elise

1976 "Familial Constraints on Women's Work Roles." Signs 1 (Supplement): 95-117.

Collet, Clara

1898 "The Collection and Utilization of Official Statistics Bearing on the Extent and Effects of the Industrial Employment of Women." Journal of the Royal Statistical Society LXI: 219-260.

Goody, Jack

1972 "The Evolution of the Family." In Laslett and Wall, eds., Household and Family in Past Time, 103-124. Cambridge: Cambridge University Press.

1973 "Polygyny. Economy and the Role of Women." In Jack Goody, ed., The Character of Kinship. Cambridge: Cambridge University Press.

1976 "Introduction." In Jack Goody, Joan Thirsk and E. P. Thompson, eds., Family and Inheritance. Rural Society in Western Europe, 1200-1800, 1-9. Cambridge: Cambridge University Press.

Hareven, Tamara and Maris Vinovskis

1974 "Patterns of Childbearing in Late Nineteenth-Century America: The Determinants of Marital Fertility in Five Essex County Towns in 1880." Unpublished paper, Clark University and University of Michigan.

1975 "Marital Fertility, Ethnicity and Occupation in Urban Families: An Analysis of South Boston and the South End in 1880." The Journal of Social History 9:69-93.

Hartman, Heidi

1976 "Capitalism. Patriarchy and Job Segrega- 
tion by Sex." Signs 1 (Supplement): 137. 169.

Jones, Gareth Stedman

1974 "Working Class Culture and Working Class Politics in London, 1870-1900." Journal of Social History 7:460-508.

Katz, Michael

1975 The People of Hamilton, Canada West. Family and Class in a Mid-Nineteenth-Century City. Cambridge, Mass.: Harvard University Press.

Knoded, John

1977 "Family Limitation and the Fertility Transition: Evidence from the Age Patterns of Fertility in Europe and Asia." Population Studies 31:219-249.

Litchfield, R. Burr

1978 "The Family and the Mill: Cotton Mill Work, Family Work Patterns, and Fertility in Mid-Victorian Stockport." In A. S. Wohl, ed., The Victorian Family. London: Croom Helm.

Lloyd, Cynthia B.

1975 "The Division of Labor between the Sexes: A Review." In Cynthia B. Lloyd, ed. Sex Discrimination and the Division of Labor. New York: Columbia University Press.

Mason, Karen Oppenheim; Maris A. Vinovskis and Tamara K. Hareven

1979 "Women's Gainful Employment and the Life Course in Essex County, Massachusetts, 1880." In Tamara K. Hareven, ed.,
The Life Course and the Family Cycle in Historical Perspective. New York: Academic Press.

Meillassoux, Claude

1975 Femmes, greniers et capitaux. Paris: Maspero.

Modell, John and Tamara K. Hareven

1973 "Urbanization and the Malleable Household: An Examination of Boarding and Lodging in American Families." Journal of Marriage and the Family: 467-471.

Reybaud, Louis

1863 Le coton, Son régime, ses problèmes. Son influence en Europe. Paris: Calman-Lévy. Roubaix

1873 Rapport sur l'administration et la situation des affaires de la ville de Roubaix pendant l'année 1872 , presenté par $M$. le Maire au Conseil Municipal. Roubaix: Beghin.

1907 Rapport sur l'administration et la situation des affaires de la ville de Roubaix pendant l'année 1906, presenté par M. le Maire au Conseil Municipal. Roubaix: Reboux.

Smith, Thomas C.

1977 Nakahara. Stanford: Stanford University Press.

Thorner, Daniel; Basile Kerblay and R. E. F. Smith, eds.

1966 A. V. Chayanov on the Theory of Peasant Economy. Homewood, Illinois: Richard Irwin. 